\title{
RYZYKO FINANSOWE W KONTEKŚCIE ZADŁUŻENIA JEDNOSTEK SAMORZĄDU TERYTORIALNEGO W POLSCE
}

\begin{abstract}
Streszczenie
Samorząd terytorialny działa w warunkach niepewności i ryzyka. Ich negatywne skutki powodują że samorząd nieoptymalnie realizuje swoje zadania. Jednym z rodzajów ryzyka towarzyszącego samorządowi terytorialnemu jest ryzyko finansowe. W opracowaniu wyjaśniono istotę i źródła tego typu ryzyka. Skupiono się na zadłużeniu jako kluczowym obszarze kreacji ryzyka finansowego. Na podstawie danych empirycznych dokonano analizy zadłużenia sektora samorządowego w Polsce w latach 2005-2013. W kontekście ryzyka finansowego określono istniejące oraz potencjalne konsekwencje nadmiernego zadłużenia jednostek samorządu terytorialnego.
\end{abstract}

Słowa kluczowe: jednostki samorządu terytorialnego, ryzyko finansowe, zadłużenie

\section{FINANCIAL RISK AND LOCAL GOVERNMENT DEBT IN POLAND}

\section{Summary}

Local governments operate in conditions of uncertainty and risk. Their negative consequences cause LGUs to perform their tasks in a suboptimal way. One of the risks associated with local governments is the financial risk. The paper explains the nature and source of this type of risk. The author focuses on debt as a key area of the creation of financial risk. The indebtedness of the Polish local government sector from 2005 to 2013 is analysed on the basis of empirical data. In the context of financial risk, the existing and the potential consequences of over-indebtedness of local governments are identified and described.

Key words: local government units, financial risks, debt

\section{Wstęp}

Gospodarowanie finansami w jednostce samorządu terytorialnego (JST), aby spełniło postawione przed nim zadania, winno polegać na [Filipiak, 2011, s. 37]:

\footnotetext{
${ }^{1}$ Dr hab. Ryszard Kata, prof. UR - Wydział Ekonomii, Uniwersytet Rzeszowski; e-mail: rdkata@ univ.rzeszow.pl.
} 
- odpowiednim kształtowaniu krótko- i długoterminowej struktury kapitałowo-majątkowej;

- optymalnej alokacji posiadanych zasobów finansowych, tak aby doprowadzić do minimalizacji ryzyka przy jednoczesnym zwiększeniu efektywności realizowanych zadan;

- monitorowaniu, analizowaniu i prognozowaniu sytuacji finansowej z wykorzystaniem odpowiednich narzędzi prognostycznych i analitycznych;

- $\quad$ wytyczaniu strategii finansowania;

- odpowiedniej polityce inwestycyjnej;

- $\quad$ polityce i strategii zarządzania samorządowym długiem publicznym;

- oddziaływaniu na poziom ryzyka towarzyszącego podejmowanym decyzjom.

Kluczowe znaczenie dla finansów JST ma zatem kontrola i zarządzanie zadłużeniem jednostki oraz zarządzanie ryzykiem finansowym. Te dwie kwestie są pochodna prowadzenia gospodarki finansowej we wszystkich jej obszarach, ponadto sa ze sobą ściśle powiazane. Zależność ta jest dwustronna, bowiem powstawanie i wzrost samorządowego długu skutkuje wzrostem ryzyka finansowego w działalności JST. Z drugiej strony rosnące ryzyko finansowe powoduje, że koszty pozyskania każdej kolejnej jednostki finansowania obcego są wyższe, gdyż stopa zwrotu z kapitału jest podwyższona z tytułu premii za ryzyko. Przy wysokim poziomie ryzyka finansowego kapitałodawcy (np. banki) mogą w ogóle odmówić finansowania danej JST.

W niniejszym opracowaniu podjęto próbę wyjaśnienia istoty ryzyka finansowego w działalności jednostek samorząa terytorialnego oraz jego powiązań z zadłużaniem tych podmiotów. Ponadto dokonano analizy zadłużenia sektora samorządu terytorialnego w Polsce w latach 2005-2013 oraz jego konsekwencji dla gospodarki finansowej JST przez wpływ zadłużenia na ryzyko finansowe. Głównym źródłem materiałów empirycznych były statystyki Ministerstwa Finansów, GUS oraz Krajowej Rady Regionalnych Izb Obrachunkowych w Warszawie.

\section{Istota ryzyka finansowego $w$ jednostkach samorządu terytorialnego}

Jednostkom samorządu terytorialnego, tak jak innym podmiotom funkcjonującym w sferze społecznej i gospodarczej towarzyszy ryzyko i niepewność. Frank Knight w swoim dziele pt:: Risk, Uncertainty and Profit [Knight, 1921] sformułowal, klasyczna już, koncepcję ryzyka jako niepewności mierzalnej. Twierdził, że ryzyko oznacza możliwe odchylenia od stanów oczekiwanych, które dają się przewidzieć i zmierzyć za pomocą rachunku prawdopodobieństwa. Natomiast niepewność sensu stricto utożsamił on z niemożnością podjęcia racjonalnej decyzji wobec braku informacji o przyszłych wydarzeniach (niepewności nie można oszacować). Wzajemne relacje między ryzykiem a niepewnością określił także Pfeffer [Pfeffer, 1956, s. 42], który twierdził, że ryzyłko jest mierzone prawdopodobieństwem, zaś niepewność jest mierzona prz̨ez poziom wiary. Rysyko jest stanem swiata - niepewność jest stanem umystu.

William D. Rowe [Rowe, 1977] łączył ryzyko z możliwością urzeczywistnienia czegoś niepożądanego, negatywną konsekwencją pewnego zdarzenia. W tym ujęciu, ryzyko 
definiuje się jako niebezpieczeństwo: błędnych rozstrzygnięć (decyzji), niepowodzenia działania, negatywnego odchylenia od celu [Borys, 1997; Domański, 2011].

$\mathrm{Z}$ działalnością jednostek samorządu terytorialnego wiaże się wiele różnego rodzaju ryzyk, takich jak: operacyjne, inwestycyjne itd. Jednym z nich, oddziałujących wprost na stabilność finansów danej JST, jest ryzyko finansowe. Ryzyko to łączy się z podejmowaniem decyzji dotyczących struktury i sposobów finansowania zadań jednostki samorządu terytorialnego [Kosek-Wojnar, 2005; Filipiak, 2011, s. 227]. Mając na uwadze to, że dochody JST zwykle nie są wystarczające na pokrycie wszystkich potrzeb finansowych obejmujących realizację zadań publicznych (zwłaszcza tych o charakterze rozwojowym), samorządy terytorialne są zmuszone sięgać po zewnętrzne źródła finansowania. Wśród nich zasadniczą rolę odgrywają kapitały tworzące dług. Ryzyko finansowe jest zatem związane $z$ zadłużeniem JST, przy czym znaczenie ma nie tylko poziom i struktura zadłużenia danej jednostki, ale także odpowiednie rozplanowanie spłat kredytów czy pożyczek z właściwym uwzględnieniem kosztów obsługi długu [Kata, 2012, s. 130]. Ryzyko finansowe wiąże się także z nieosiagnięciem oczekiwanych dochodów lub odchyleniami od oczekiwanych dochodów [Jajuga, 2007, s. 131].

RYSUNEK 1.

Kluczowe obszary kreacji ryzyka finansowego w JST

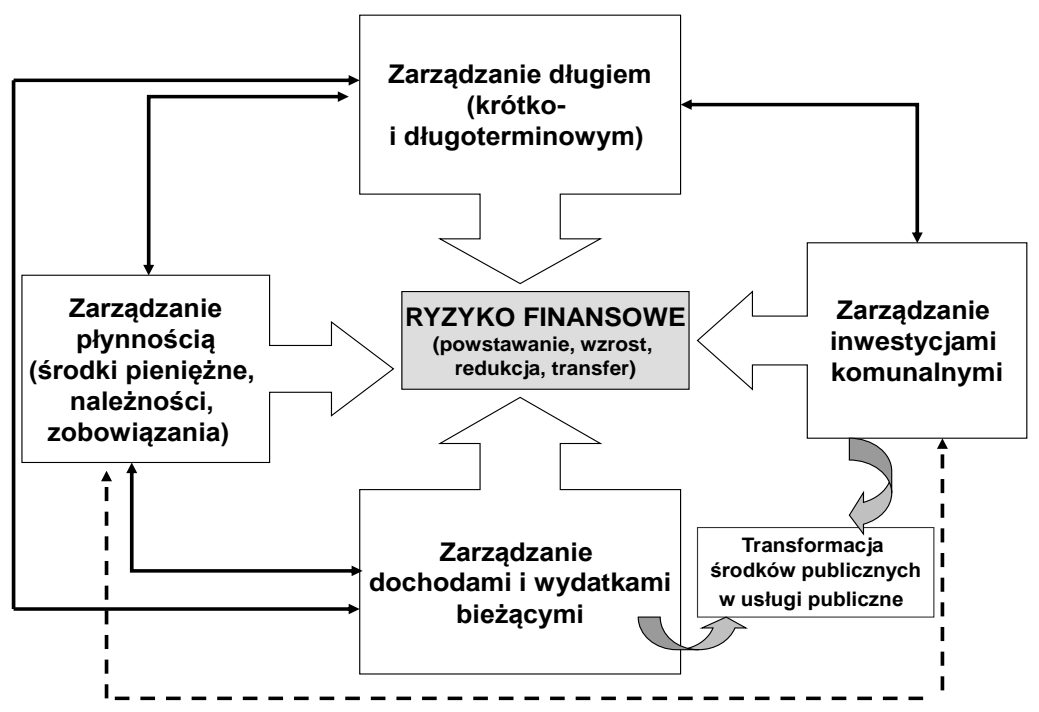

Źródło: opracowanie własne.

Warto podkreślić, iż ryzyko finansowe ma swoje źródła endogeniczne (zarządzanie płynnością, zadłużenie, realizowane inwestycje itd.) oraz źródła egzogeniczne (zmiany stóp procentowych, warunków pozyskania kredytów itd.). Ryzyko to powstaje w różnych obszarach działalności JST (rysunek 1.), gdyż jest związane z pozyskaniem środ- 
ków finansowych, zarówno na zabezpieczenie płynności danej jednostki, jak i realizację zadań bieżących i inwestycyjnych. Niemniej wszystkie wymienione obszary kreacji ryzyka finansowego są powiązane ze sobą oraz wpływają na kształtowanie się długu jednostki samorządu terytorialnego (rysunek 1.). Stąd poziom zadłużenia i jakość zarządzania samorządowym długiem mają kluczowe znaczenie dla ryzyka finansowego.

Ryzyko finansowe oddziałuje na sytuację finansowa JST oraz jej zdolność do wywiązywania się z zobowiązań. Negatywne skutki tego ryzyka mogą dotyczyć zarówno krótkiego okresu, jak i moga być długofalowe i wpływać na zdolność JST do kreowania lokalnego rozwoju społeczno-gospodarczego. Potencjalne negatywne skutki ryzyka finansowego dla JST (uszeregowane według kryterium czasu ich oddziaływania) to m.in.:

- utrata płynności;

- $\quad$ utrata wypłacalności, zdolności kredytowej;

- $\quad$ utrata wiarygodności (jako: dłużnik, partner handlowy, inwestor, dostawca usług publicznych);

- $\quad$ utrudniony dostęp do zewnętrznych środków finansowych (długu), wyższy koszt kapitału;

- brak możliwości rolowania długu;

- konieczność „cięcia” wydatków, zmniejszenie poziomu usług publicznych, pogorszenie jakości tych usług itd.;

- ograniczenie lub brak możliwości realizowania inwestycji;

- $\quad$ utracone korzyści wynikające z ograniczenia bądź braku możliwości absorpcji funduszy Unii Europejskiej wspierających rozwój lokalny.

Zważywszy na fakt, iż ryzyko finansowe może mieć tak istotne konsekwencje dla wielkości i jakości usług publicznych świadczonych przez samorząd, finansów jednostki czy zakresu inwestycji w rozwój lokalny, organy samorządowe powinny przyjmować określona postawę wobec ryzyka oraz skutecznie i efektywnie nim zarządzać (rysunek 2.).

Ryzyku finansowemu należy przeciwdziałać, co może być realizowane przez: unikanie ryzyka, ograniczanie jego wielkości (prawdopodobieństwa wystapienia negatywnych skutków), łagodzenie jego negatywnych efektów, przenoszenie (transferowania) czy też zabezpieczanie się (np. przez ubezpieczenia). Jednak skuteczne zarządzanie ryzykiem finansowym wymaga działania w sposób ciagły i planowy oraz podejścia procesowego, którego istotę zaprezentowano na rysunku 2. 
RYSUNEK 2.

\section{Podejście procesowe do zarządzania ryzykiem w finansach JST}

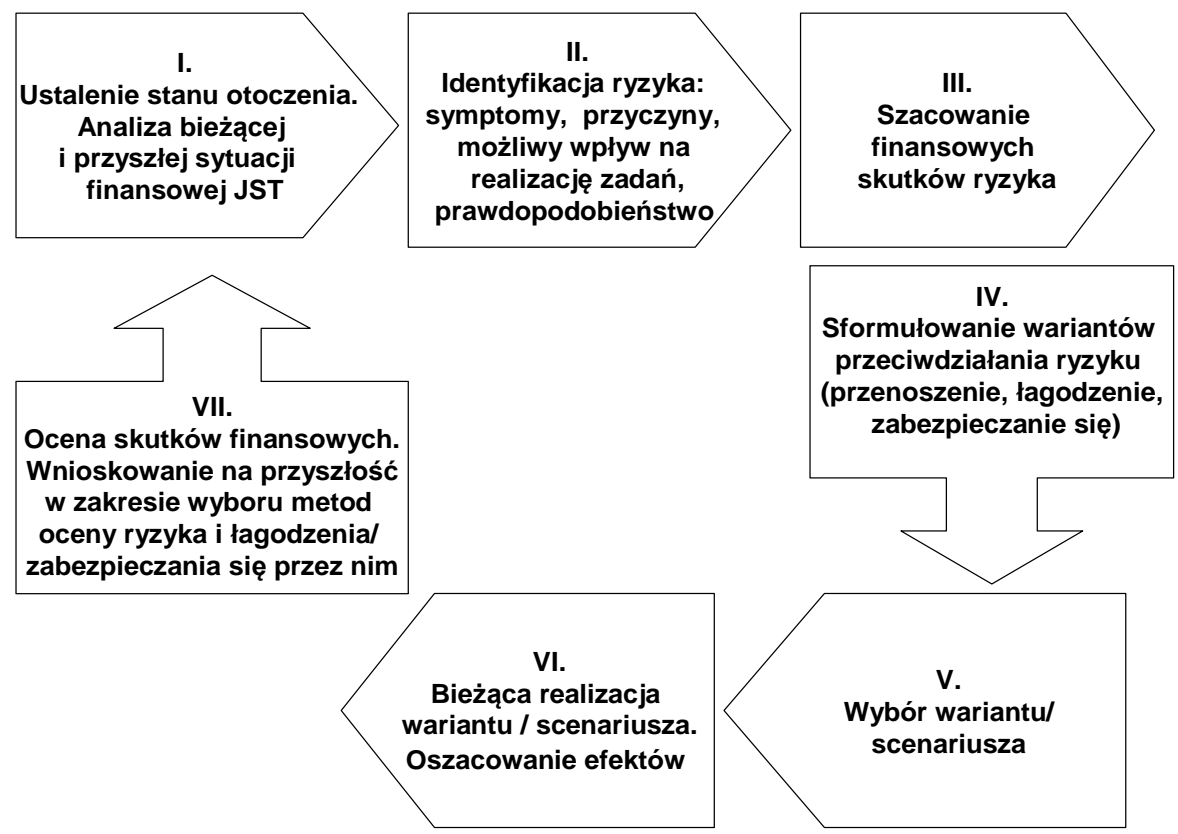

Źródło: opracowanie własne na podstawie: [Filipiak, 2011, s. 319-320].

\section{Zadłużenie jako czynnik wzrostu ryzyka finansowego jednostek samorządu terytorialnego w Polsce}

Zadłużenie JST można zdefiniować jako sumę środków postawionych do dyspozycji jednostki samorządowej na określony czas i na ustalonych warunkach. Zadłużenie stanowi zatem finansowe zobowiązanie władz samorządowych wobec podmiotów zewnętrznych, które podlega spłacie. Dług jest obarczony ryzykiem finansowym, które dotyczy samej jednostki (dłużnika), ale także dług JST, będąc składową całego samorządowego długu publicznego, rodzi ryzyko w stosunku do społeczeństwa. Utrzymywanie bezpiecznego poziomu zadłużenia, ze względu na potencjalne konsekwencje wynikającego stąd ryzyka, jest zatem działaniem zarówno w interesie danej jednostki samorządowej, jak i w interesie społecznym.

Ważne jest, aby organy prowadzace gospodarkę finansową JST kształtowały odpowiednią struktura finansowania i zarządzały zobowiązaniami krótko- i długoterminowymi w sposób planowy i procesowy, przy uwzględnieniu czynników wewnętrznych oraz uwarunkowań zewnętrznych. Do tych ostatnich można zaliczyć m.in.: sytuację na rynku finansowym, poziom stóp procentowych i potencjalne ich zmiany i poziom zadłużenia innych JST, całego podsektora samorządowego i sektora finansów publicznych ogółem. Wszystkie te elementy oraz wewnętrzna sytuacja ekonomiczno-finan- 
sowa jednostki mogą wpływać na ocenę poziomu zadłużenia i związanego z tym ryzyka finansowego. Jego poziom w kontekście zadłużenia jest wielkością względną. Zadłużenie, które w stosunku do jednej jednostki w określonej sytuacji wewnętrznej, a także danych warunkach egzogenicznych można uznać za wysokie i generujące duże ryzyko finansowe, w odniesieniu do innej (dysponującej np. znacznie większą samodzielnością finansowa) za zupełnie bezpieczne.

W Polsce występuje dosyć duże zróżnicowanie w poziomie i dynamice zadłużenia JST. W ostatnich latach można obserwować systematyczny wzrost zadłużenia całego podsektora samorządowego, chociaż trzeba podkreślić, iż bardzo wysoka dynamika przyrostu zadłużenia, jaka miała miejsce w latach 2008-2011, została znacznie wyhamowana (rysunek 3.). Miało na to wpływ kilka czynników, m.in. wprowadzenie w Ustawie z. dnia 27 sierpnia 2009 roku o finansach publicznych (Dz. U. Nr 157, poz. 1240, art. 243; dalej UoFP) indywidualnego wskaźnika zadłużenia (art. 243), który mocno limituje pojemność zadłużeniowa, czyli zdolność do zaciagania kolejnych zobowiązań przez JST [Kata, 2012, s. 135]. Co prawda, ta nowa reguła fiskalna weszła w życie z początkiem 2014 roku, jednak parametry potrzebne do wyliczenia wskaźnika dla roku 2014 dotyczyły także dwóch poprzednich lat (2012 i 2013), stąd samorządy, przygotowując się do wprowadzenia tego miernika, już od roku 2012 starały się ograniczać dalszy wzrost zadłużenia.

RYSUNEK 3.

\section{Zobowiązania JST w Polsce w latach 2005-2013 - kwota (w mld zł) i stopa} wzrostu (w \%)

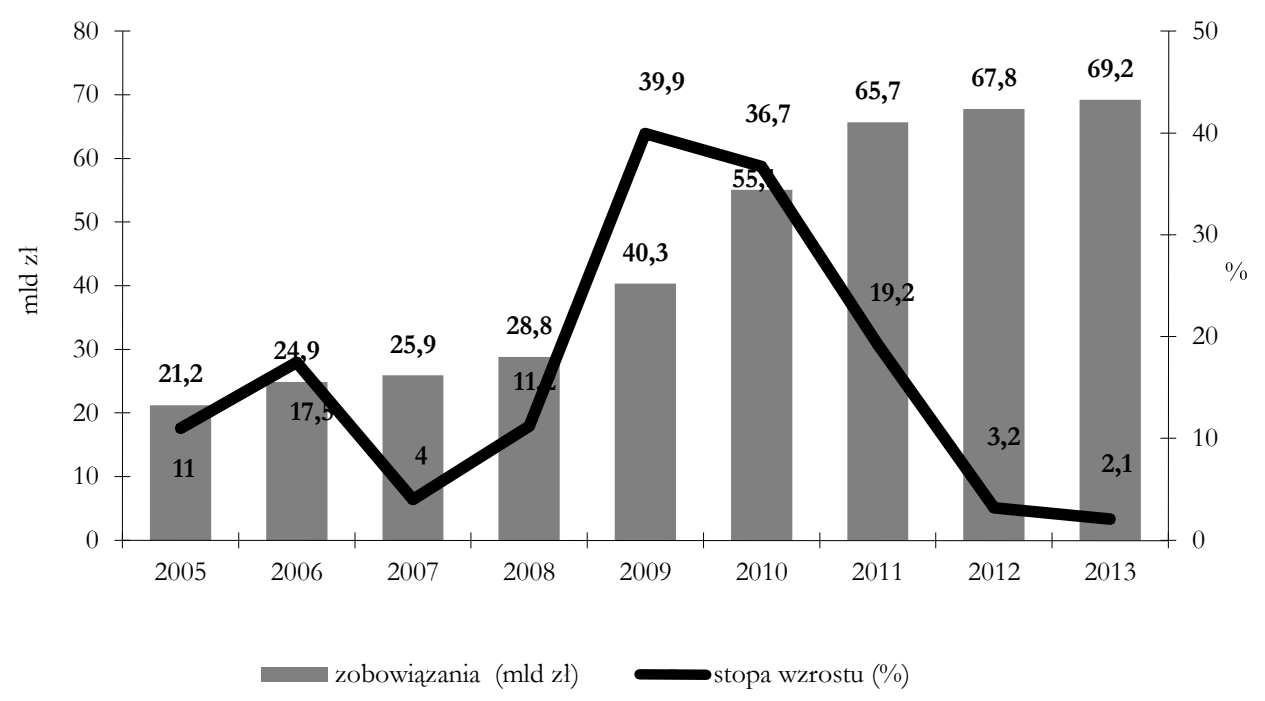

Źródło: opracowanie własne na podstawie danych Ministerstwa Finansów i GUS.

W latach 2005-2013 zadłużenie podsektora samorządowego wzrosło nominalnie o $226,4 \%$, czyli ponad trzykrotnie, zaś realny wzrost wyniósł 161,1\%. We wszystkich 
tych latach zadłużenie nominalnie rosło (najszybciej, gdyż prawie 40\% w roku 2009 i 2010), natomiast uwzględniając inflację (wskaźnik CPI), realny spadek zadłużenia (o $0,5 \%)$ miał miejsce jedynie w roku 2012.

W miastach na prawach powiatu oraz gminach można zaobserwować najwyższą wartość zadłużenia (rysunek 4.). Podobnie jak w całym sektorze samorządowym, zadłużenie tych jednostek wzrastało najszybciej w latach 2008-2011. W przypadku miast na prawach powiatu nominalnie zadłużenie w całym badanym okresie (2005-2013) wzrosło o 197,1\%, zaś realnie o 137,7\%. Jedynie w roku 2007 zadłużenie nie wzrosło (w rzeczywistości nastapił jego niewielki spadek o 2,4\%).

RYSUNEK 4.

Zobowiązania według kategorii JST w latach 2005-2013 (w mld zł)

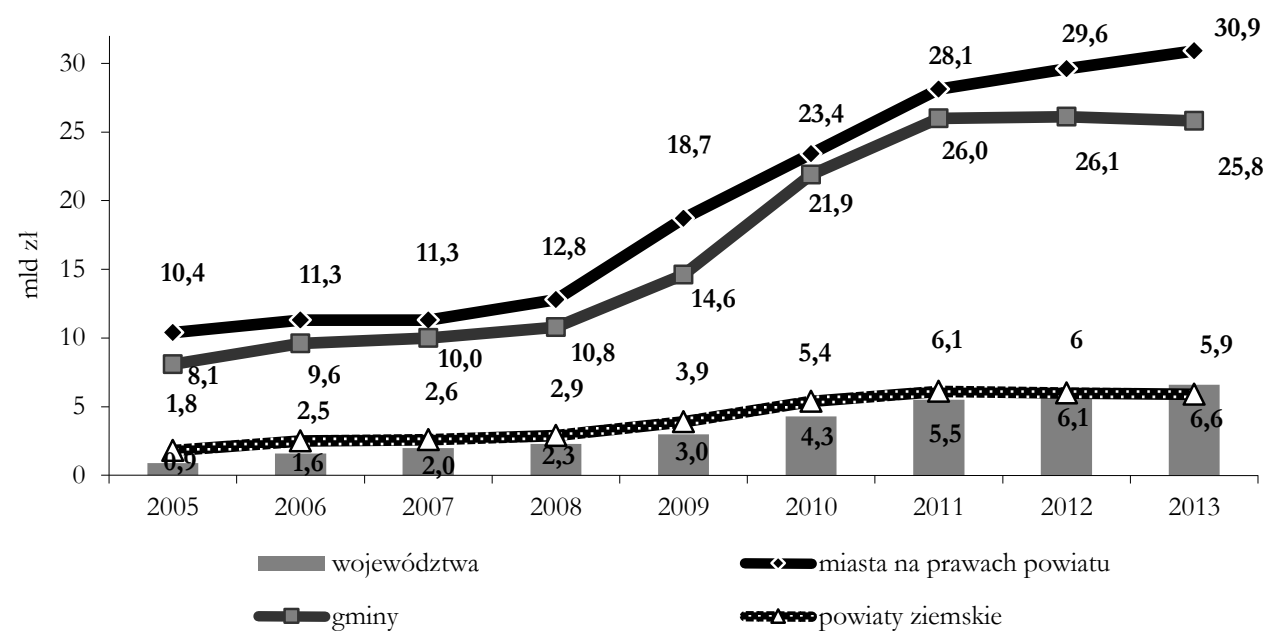

Źródło: jak na rysunku 1.

W gminach zadłużenie rosło nominalnie i właściwie nieprzerwanie do 2011 roku, po czym nastąpił jego niewielki spadek (rysunek 4.). Faktycznie zadłużenie gmin zmniejszyło się na koniec roku 2013 o 4,3\% w stosunku do najwyższego poziomu z końca 2011 roku. Jednakże w całym badanym okresie zadłużenie gmin wzrosło istotnie o 155\% (nominalnie o 218,5\%). Tak duży wzrost długów jest kluczowym czynnikiem determinującym ryzyko finansowe w działalności gmin. Świadomość tego ryzyka i jego konsekwencji, obok nowych reguł fiskalnych limitujących pojemność zadłużeniowa JST²,

\footnotetext{
2 Przez pojemność zadłużeniową rozumie się tu maksymalną kwotę długu, jaką w zgodzie z regulacjami ustawowymi będzie mogła zaciagnąć dana JST [Czudec, Kata, 2013, s. 16]. Tak interpretowana „regulacyjna” pojemność zadłużeniowa nie jest tożsama z pojemnością zadłużeniową w ujęciu nauki finansów, przez którą rozumie się maksymalną kwotę długu, jaką jest w stanie zaciagnąć dana jednostka na rynku finansowym [Gajdka, 2002, s. 64].
} 
była kluczowym czynnikiem skłaniającym władze gmin do ograniczenia dalszego wzrostu zadłużenia w latach 2012-2013.

W przypadku powiatów ziemskich, podobnie jak w gminach, zadłużenie rosło nieprzerwanie do końca 2011 roku. W latach 2012-2013 nastapił jego niewielki spadek w stosunku do roku 2011, zarówno w ujęciu nominalnym (o 3,3\%), jak i realnym (o 7,6\%). Ogólnie, w latach 2005-2013 zadłużenie powiatów wzrosło realnie o 162,2\% (nominalnie o $227,8 \%$ ).

Z kolei w samorządowych wojewódzkich można zaobserwować wzrost zadłużenia także w latach 2012-2013, chociaż jego dynamika uległa wyraźnemu spowolnieniu wobec lat 2008-2011. Województwa samorządowe zanotowały największy wzrost zadłużenia spośród wszystkich rodzajów JST. Ich dług w latach 2005-2013 wzrósł nominalnie o $633,3 \%$, zaś realnie o 486,6\%.

Miara wzrostu zadłużenia jednostek samorządu terytorialnego na przestrzeni kilku ostatnich lat jest również relacja zobowiązań JST do osiagniętych w danym roku dochodów budżetowych, tj. wskaźnik ogólnego zadłużenia (WZU) według UoFP z 30 czerwca 2005 roku (Dz. U. Nr 249, poz. 2104). W przypadku całego sektora samorządowego relacja ta wzrosła z 21,3\% w roku 2006 do $37,7 \%$ w roku 2013, natomiast pomijając zobowiązania zaciagnięte na projekty współfinansowane ze środków unijnych, WZU wynosił 32,1\%. Na rysunku 5. zaprezentowano, jak kształtowała się ta relacja w poszczególnych rodzajach JST.

Podobnie jak wolumen zobowiązań JST, tak wskaźnik ogólnego zadłużenia wzrastał szczególne szybko w latach 2008-2011 (rysunek 5.). W kolejnych latach wskaźnik ten uległ nieznacznemu spadkowi (w przypadku województw samorządowych spadek nastapił dopiero w 2013 roku). W latach 2012-2013 można mówić o ustabilizowaniu zadłużenia jednostek samorządu terytorialnego, jednakże na bardzo wysokim (miasta na prawach powiatu) lub wysokim jego poziomie (pozostałe grupy JST). Rodzi to określone ryzyko finansowe wyrażające się zagrożeniem zdolności do regulowania zobowiązań przez władze samorządowe oraz ograniczeniem możliwości pozyskania przez nie kolejnych źródeł finansowania. Wpływa także na koszty finansowania obcego.

Należy podkreślić, iż na koniec 2013 roku co ósma jednostka samorządu terytorialnego $(11,4 \%$ ) osiagnęła wskaźnik ogólnego zadłużenia (według art. 170, ust. 1, UoFP z 2005 roku) na poziomie zbliżonym do górnej granicy 60\% (ti. od 50 do 60\%) lub już przekroczyła ten próg ogólnego zadłużenia. Jeszcze w roku 2011 takich JST było dwukrotnie mniej (5,9\%). Wysokie zadłużenie dotyczyło jednocześnie jednostek, które notowaky zobowiązania w relacji do uzyskiwanych dochodów na poziomie od 30 do $50 \%$. Takich JST na koniec 2013 roku było 37\% (w przypadku gmin 38\%). W roku 2011 ogółem takich JST było $27,7 \%$, zaś gmin 28,8\%. Mając powyższe na uwadze, można stwierdzić, iż wysokie ryzyko finansowe, będące pochodną wysokiego zadłużenia (WZU powyżej 30\%), dotyczyło na koniec 2013 roku ogólnie co drugiej jednostki samorządu terytorialnego (48,4\%), zaś biorąc pod uwagę tylko gminy, 49,3\% jednostek. W stosunku do stanu z przed dwóch lat (koniec 2011 roku) oznacza to wzrost udziału tego typu JST o 14,8 p.p. (w przypadku gmin o 14 p.p.). Te wielkości najdobitniej ilustrują wzrost ryzyka finansowego, jakie wiąże się z zadłużeniem JST w Polsce. 
RYSUNEK 5.

Relacja zobowiązań JST do ich dochodów budżetowych w latach 2006-2013 $(\mathrm{w} \%)^{*}$

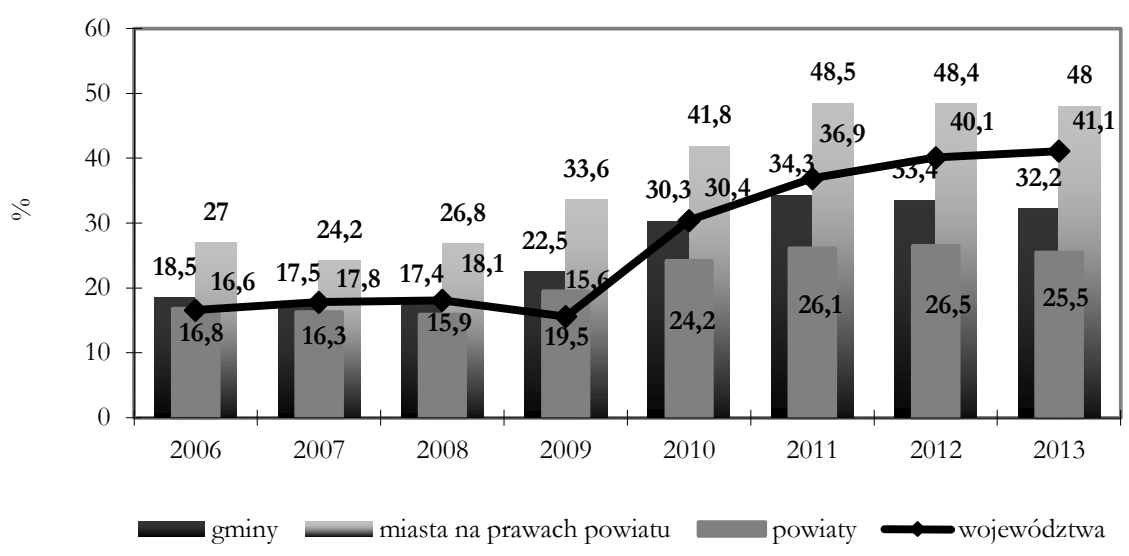

* Wskaźnik zadłużenia na podstawie: art. 170, ust.1 UoFP z 2005 roku.

Źródło: jak na rysunku 1.

Zadłużenie sektora samorządowego stanowi część państwowego długu publicznego, tak jak finanse samorządu terytorialnego są częścią finansów publicznych. Nadmierne zadłużenie sektora local government generuje ryzyko dla całego systemu finansów publicznych. To zagregowane zadłużenie jest istotne także z punktu wiedzenia poszczególnych JST. Nadmierny wzrost samorządowego długu publicznego oraz wzrost jego udziału w państwowym długu publicznym (PDP) lub jego relacji w stosunku do PKB może skłaniać władze publiczne (rząd, parlament) do wprowadzania różnych regulacji prawnych i reguł fiskalnych, które będą limitować możliwości dalszego zadłużenia się przez JST. Sytuacja taka miała miejsce w Polsce w ostatnich latach. Reguły fiskalne, wprowadzone m.in. w Ustawie o finansach publicznych z. 27 sierpnia z. 2009 roku, ograniczają swobodę prowadzenia gospodarki finansowej JST, wpływając m.in. na strukturę i sposoby finansowania zadań publicznych przez samorząd terytorialny.

Udział jednostek samorządu terytorialnego w PDP w latach 2002-2008 kształtował się na poziomie około 4\% lub nieznacznie więcej (rysunek 6.). W latach 2009-2011 nastapił jego wzrost do blisko 8\%. Wynikało to z faktu, iż zadłużenie podsektora samorządowego rosło w latach 2009-2011 średnio na poziomie 30,4\%, zaś zadłużenie podsektora rządowego średnio na poziomie 9,7\%. Jak wykazano wcześniej, dynamika zadłużenia JST została znacząco wyhamowana w latach 2012-2013, co spowodowało nieznaczne zmniejszenie udziału podsektora samorządowego w PDP (do poziomu $7,2 \% \mathrm{w}$ roku 2013). 
RYSUNEK 6.

Udział JST w państwowym długu publicznym oraz w relacji do PKB (w \%) w latach 2002-2013

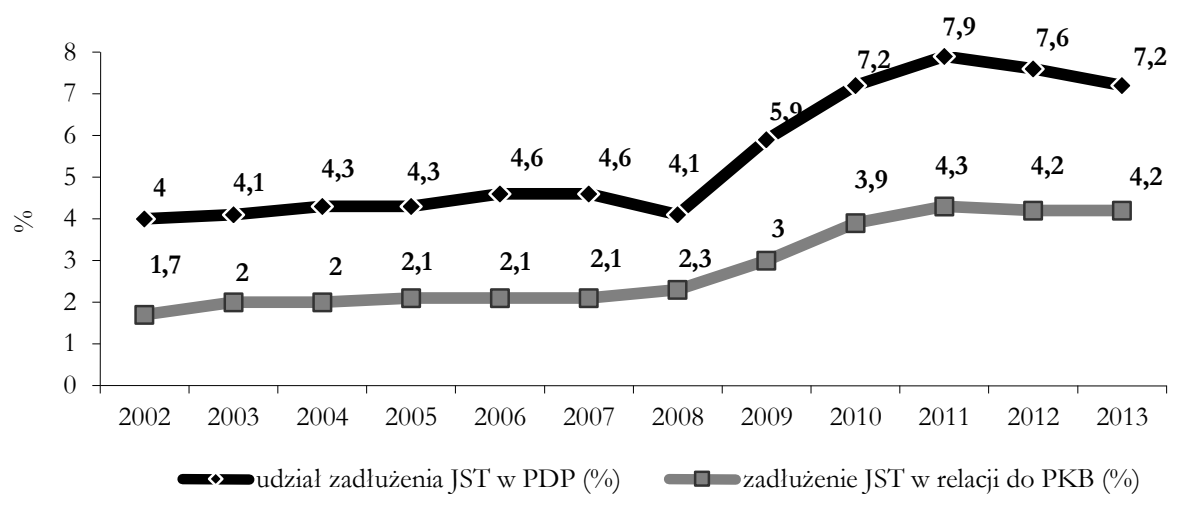

Źródło: jak na rysunku 1.

W zakresie relacji do PKB dług jednostek samorządu terytorialnego wzrósł 2,5-krotnie w stosunku do poziomu z roku 2002 (rysunek 6.). Co prawda, przeciętne zadłużenie sektora local government $\mathrm{w}$ relacji do PKB było w Unii Europejskiej nieco wyższe (w 2011 roku wynosiło ono 5,9\%), natomiast w niektórych krajach przekraczało 8\% (Holandia, Francja, Włochy), to jednak w latach 2008-2011 w Polsce zadłużenie to przyrastało najszybciej spośród wszystkich krajów członkowskich Unii Europejskiej [Poniatowicz, 2012, s. 315].

\section{Przyczyny i skutki wzrostu zadłużenia jednostek samorządu terytorialnego w Polsce}

Literatura przedmiotu dostarcza wielu oryginalnych teorii i koncepcji tłumaczacych zjawisko deficytu budżetowego, a także, pochodne deficytowi, zjawisko rosnącego zadłużenia sektora finansów publicznych, w tym również podsektora samorządowego. Nie wdając się w szczegółowy opis tych teorii, można wyróżnić następujące, teoretyczne koncepcje wyjaśniające zjawisko deficytu budżetowego i rosnącego zadłużenia:

- prawo wrrastajacych uydatkón publicznych $A$. Wagnera (rosnące wydatki, nie mając pokrycia w dochodach, tworzą presję na wzrost długu publicznego);

- bipoteza neutralności dtugu publicznego (R. J. Barro) - przekonanie, że finansowanie zwiększonych wydatków publicznych jest mniej szkodliwe dla gospodarki przez zaciagnięcie długu, niż przez wzrost podatków;

- $\quad$ ekspansja biurokracji i syndrom praw nabytych (J. Schumpeter);

- sketonnoś́ do deficytu (ang. deficit bias) ze strony polityków ze względu na ich krótkoterminowy interes polityczny; 
- teoria politycznego cyklu koniunkturalnego - wzrost wydatków budżetowych i deficytu w okresach przedwyborczych;

- problem wspólnej puli zasobów (ang. common pool) - dążenie do podwyższania wydatków i deficytu przez wpływowe grupy interesu;

- efekt schodkony dlugu (ang. debt ratching) - w okresie dobrej koniunktury nadwyżki są ,konsumowane”, a w okresie złej koniunktury dług ulega szybkiemu przyrostowi;

- problem pokusy nadusycia $\mathrm{w}$ działalności jednostek podległych samorządowi terytorialnemu (np. publicznych ZOZ) [Alesina, Roubini, Cohen, 1997; Marchewka-Bartkowiak, 2010, s. 2; Owsiak, 2013, s. 320-321].

Bez wątpienia, wyżej wymienione teoretyczne przyczyny wzrostu deficytu budżetowego i długu publicznego w dużym stopniu tłumaczą wzrost samorządowego długu publicznego. Jednak w celu wyjaśnienia tego zjawiska w Polsce warto odnieść się do konkretnych procesów i zjawisk, jakie miały miejsce w jednostkach samorządu terytorialnego w ostatnich latach (rysunek 7.). Według Poniatowicz i innych [Poniatowicz i in., 2010, s. 38], przyczyny wzrostu zadłużenia tkwią w sferze działalności inwestycyjnej oraz problemach i tendencjach, które łączyły się z dochodami JST.

Wzmożoną aktywność samorządów terytorialnych w sferze inwestycyjnej należy oceniać pozytywnie, gdyż wychodzi ona naprzeciw oczekiwaniom społeczności lokalnych i regionalnych w zakresie rozwoju społeczno-gospodarczego. W efekcie inwestycji realizowanych przez samorządy terytorialne jakość wielu usług publicznych poprawiła się fundamentalnie, a także realizowano przedsięwzięcia służące dostarczaniu usług publicznych, które dotychczas były niedostępne dla społeczności lokalnych. Działalność JST w tej sferze wyraźnie przyczyniła się do rozwoju terytorialnego [Bober i in., 2013, s. 76]. Dodatkowym stymulantem procesów inwestycyjnych w sektorze JST były środki Unii Europejskiej dostępne dla samorządów na szerszą skalę od roku 2004³. Jednakże wolumen środków unijnych, przeznaczonych na rozwój terytorialny, podlegał istotnym zmianom, tj. cykliczności kształtowanej przez kolejne wieloletnie perspektywy finansowe (budżety) Unii Europejskiej4. Ponadto fundusze unijne dostępne dla JST nie wystarczają na zaspokojenie wszystkich potrzeb i oczekiwań władz samorządowych w tym zakresie. Stąd można zaobserwować swoistą konkurencję o te środki, która powoduje, iż wobec braku pokrycia wkładu własnego z funduszy budżetowych, JST są skłonne zadłużać się, aby tylko nie zaprzepaścić „unijnej szansy” na wsparcie rozwoju lokalnego czy regionalnego.

3 Przykładowo w roku 2013 połowa inwestycji realizowanych przez JST (50,4\%) była finansowana przy udziale bezzwrotnych środków zagranicznych, w tym głównie funduszy Unii Europejskiej. Udział tych środków w wydatkach inwestycyjnych JST ogółem wynosił 31,9\%. W latach poprzednich udział ten był podobny lub nawet wyższy (np. w roku 2012 odpowiednio: 51,3\% oraz 31,9\%), [Sprawozdanie z driatalności..., 2014]. Dane te wskazują, jak od kilku lat duże znaczenie w działalności inwestycyjnej JST maja fundusze Unii Europejskiej.

${ }^{4}$ Zwykle w okresie przejściowym (pomiędzy zakończeniem jednej a pełnym uruchomieniem kolejnej perspektywy finansowej) wolumen dostępnych funduszy jest niższy. 
RYSUNEK 7. Przyczyny wzrostu zadłużenia jednostek samorządu terytorialnego w Polsce

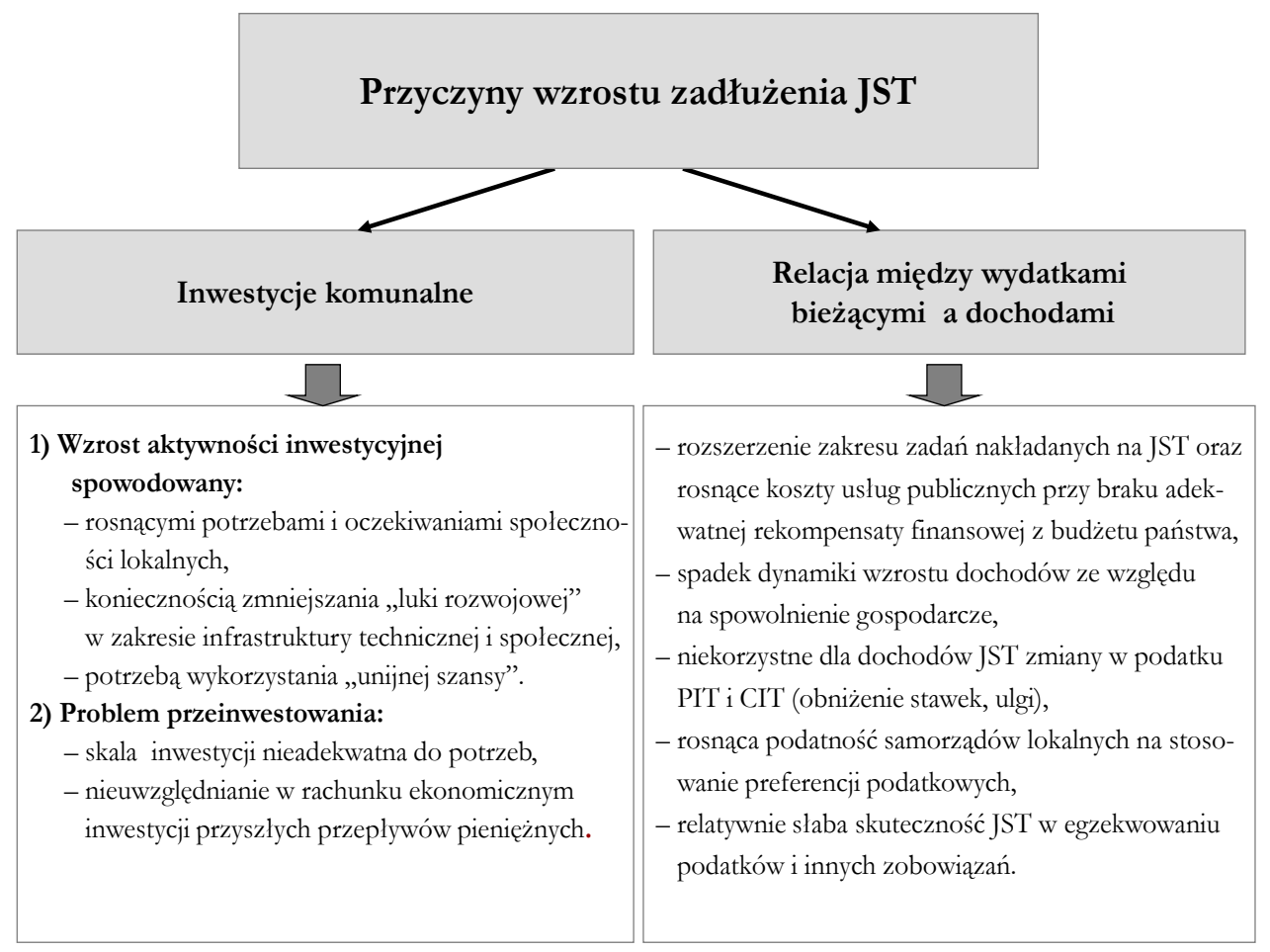

Źródło: opracowanie własne.

Problem szybko rosnącego zadłużenia JST tkwi także w niewłaściwej polityce inwestycyjnej realizowanej przez niektóre władze samorządowe. W szczególności zjawisko to dotyczy problemu przeinwestowania (rozumianego w kontekście skali inwestycji, jak i ich zasadności) obserwowanego w wielu JST [Kluza, 2013, s. 64]. Czasami ,poszukiwanie okazji” czy wprost źródeł finansowania wypiera własna, oddolną identyfikację potrzeb [Bober i in., 2013, s. 75]. W związku z tym można zauważyć przykłady budowania wielkich obiektów szkolnych w sytuacji postępującego niżu demograficznego bądź krytych pływalni (lub deklarowanej przez władze samorządowe chęci budowania) niemal w każdej gminie i dzielnicy miasta. Z tym jest także związany problem wadliwego rachunku efektywności inwestycji samorządowych, który w pełni nie uwzględnia wszystkich elementów tego rachunku, zwłaszcza zaś kosztów utrzymania (eksploatacji) obiektów infrastruktury technicznej albo społecznej, wytworzonych w drodze inwestycji komunalnych.

Wynikające z wysokiego zadłużenia ryzyko finansowe tworzy niebezpieczeństwo zablokowania samorządom terytorialnym dostępu do funduszy Unii Europejskiej z nowej perspektywy finansowej na lata 2014-2020. Zmusiło to władze wielu JST do wyhamowania dalszego zadłużania się w latach 2012-2013. Jednak wiąże się to $\mathrm{z}$ istotnym 
ograniczeniem inwestycji komunalnych. Ogółem wydatki majątkowe JST w roku 2013 zmniejszyły się nominalnie w stosunku do roku 2012 o 2,6\% (realnie o 3,5\%). W przypadku gmin spadek wydatków majątkowych wynosił nominalnie $7,2 \%$, zaś realnie ponad $8 \% \%^{5}$. Rok 2013 był trzecim z kolei, w którym wydatki inwestycyjne samorządów terytorialnych notowały spadek. W stosunku do 2010 roku wydatki inwestycyjne były niższe nominalnie o ponad $22,4 \%$, natomiast realnie spadły one do poziomu $71,1 \%$ wydatków z roku 2010 . W pewnym stopniu tak duże wyhamowanie inwestycji komunalnych łączy się z powolnym wyczerpywaniem funduszy unijnych przeznaczonych na rozwój terytorialny w ramach „starego” budżetu Unii Europejskiej 2007-2013. Niemniej ograniczenie wzrostu zadłużenia JST odbywa się również kosztem rozwoju lokalnego (wycofywaniem się samorządów z niektórych inwestycji). Dowodzi to tego, jak istotne pod względem skutecznego i efektywnego wypełniania zadań publicznych przez jednostki sektora samorządowego jest właściwe zarządzanie długiem samorządowym oraz kontrola i ograniczanie ryzyka finansowego generowanego przez nadmierne zadłużenie JST.

Inne przyczyny, które kreują wzrost deficytu budżetowego, a dalej zadłużenia sektora samorzą dowego, leża po stronie niekorzystnych tendencji obserwowanych w ostatnich latach w zakresie relacji między dochodami a wydatkami bieżącymi JST (rysunek 7.). Co prawda, nowe przepisy UoFP (art. 242) nakazuja JST równoważenie budżetu operacyjnego, jednakże niekorzystne relacje dochodowo-wydatkowe w zakresie bieżącej działalności utrudniają samorządom uzyskiwanie nadwyżki operacyjnej budżetu, która powinna być głównym źródłem wkładu własnego w finansowaniu zadań inwestycyjnych (w tym projektów dofinansowywanych ze środków Unii Europejskiej). Chcąc zatem realizować inwestycje, samorządy sięgaja po obce źródła finansowania w formie długu.

Warto podkreślić, iż rok 2007 był ostatnim, w którym JST jako sektor uzyskały nadwyżkę budżetową (w wysokości 2,3 mld zł). W kolejnych latach (2008-2013) sektor samorządowy generował deficyty budżetowe. Przy czym w latach 2008-2010 można było zaobserwować tendencję do wzrostu deficytu budżetowego, z 2,6 mld zł w roku 2008 do blisko 15 mld zł w roku 2010 (co stanowiło 9,2\% w relacji do dochodów). W kolejnych latach następował powolny, choć sukcesywny spadek deficytu budżetowego sektora z 10,2 mld zł w roku 2011 (6,0\% w relacji do dochodów), poprzez 3,0 mld zł w roku 2012 (1,7\%), do niespełna 0,4 mld zł w 2013 roku (0,2\%). W roku 2013 jedynie miasta na prawach powiatu oraz województwa samorządowe zamknęły rok niedoborem, pozostałe grupy JST wygospodarowały nadwyżkę budżetowa. Zakumulowany deficyt budżetowy sektora JST w latach 2008-2013 wyniósł jednak aż 44,1 mld zł, co nie pozostało bez wpływu na pogłębiające się zadłużenie całego sektora local government i poszczególnych jednostek. Nawet w roku 2013, relatywnie korzystnym pod tym względem, 40,4\% JST (w tym połowa województw samorządowych i $2 / 5$ gmin) zanotowało deficyt budżetowy.

\footnotetext{
${ }^{5}$ Pozostałe grupy JST zanotowały nieznaczny, nominalny wzrost wydatków majątkowych, jednakże wzrost realny na poziomie $1 \%$ dotyczył tylko powiatów.
} 
$\mathrm{Na}$ niekorzystne tendencje w zakresie relacji dochodowo-wydatkowych składa się także postępujący proces rozszerzania zadań nakładanych na JST przez władze publiczne szczebla centralnego, w ślad za czym nie idą odpowiednie transfery finansowe $z$ budżetu państwa. Mamy zatem do czynienia z asymetrycznościa (na niekorzyść JST) pomiędzy decentralizacją zadań a decentralizacją finansów publicznych. Z drugiej strony spowolniony wzrost gospodarczy w Polsce, obserwowany od 2008 roku, powoduje zmniejszenie dochodów własnych JST (głównie podatkowych), co jeszcze pogłębiają niekorzystne dla samorządów zmiany w przepisach dotyczących podatków: CIT i PIT [Owsiak, 2011, s. 173-184]. Ponadto występują jednocześnie cykle fiskalne w zakresie kształtowania źródeł finansowania samorządów. Jak zauważa Guziejewska [Guziejewska, 2007, s. 77], w sytuacji kryzysu gospodarczego (również fiskalnego) władze centralne mają tendencję do centralizacji finansów publicznych i zmniejszenia niezależności finansowej samorządów terytorialnych. Taki proces można obserwować w Polsce w ostatnich latach, czego symptomem jest coraz większe uzależnienie JST od środków transferowanych z budżetu centralnego.

Na rysunku 8. zaprezentowano potencjalne lub występujące już czynniki (źródła) wzrostu ryzyka finansowego jednostek samorządu terytorialnego w Polsce. Czynniki te są bezpośrednio związane z zadłużeniem JST bądź też, dotykając innych obszarów gospodarki finansowej JST, moga wpływać na poziom zadłużenia samorządu terytorialnego i kreować ryzyko finansowe.

Wśród czynników ryzyka, obok problemu wysokiego i wciąż rosnącego (w ujęciu monetarnym) zadłużenia JST w ostatnich latach, istotne znaczenie moga mieć nowe reguły fiskalne. W szczególności chodzi o zasadę równoważenia budżetu operacyjnego oraz nowy, indywidualny wskaźnik zadłużenia (IWZ). Reguły te w zamyśle ustawodawcy mają chronić samorząd terytorialny przed nadmiernym zadłużeniem i wynikającym z tego ryzykiem finansowym. Reguła równoważenia budżetu operacyjnego obowiązuje od 2011 roku, zaś IWZ od roku 2014 [Marchewka-Bartkowiak, 2010, s. 6]. Bez watpienia, wyhamowanie wzrostu zadłużenia w sektorze samorządowym można w jakimś zakresie przypisać oddziaływaniu wymienionych reguł (w przypadku IWZ było to oddziaływanie prewencyjne). Niemniej funkcjonowanie tych reguł może tworzyć ryzyko o nieco innym charakterze. Jak podkreśla Surówka, [Surówka, 2014, s. 5] w wielu samorządach istnieje realne niebezpieczeństwo przekroczenia indywidualnego, dopuszczalnego wskaźnika zadłużenia. Stanowi to naruszenie prawa, stąd zadłużone samorządy ograniczaja swoje wydatki, a także (co jest dużym niebezpieczeństwem) zaciagają kredyty konsolidacyjne, przerzucając dług publiczny na przyszłe pokolenia. Ponadto chęć utrzymania pojemności zadłużeniowej, przy obecnej konstrukcji algorytmu IWZ, może skłaniać JST do sprzedaży majątku komunalnego, co w przyszłości będzie ograniczać ich potencjał dochodowy i możliwości kreowania rozwoju terytorialnego. 
RYSUNEK 8.

\section{Czynniki wzrostu ryzyka finansowego powiązane z zadłużeniem jednostek samorządu terytorialnego w Polsce}

\section{CZYNNIKI (ŹRÓDŁA) RYZYKA}

Rosnące zadłużenie całego sektora publicznego
i wzrastający udział JST w państwowym
długu publicznym (PDP)

\section{POTENCJALNE SKUTKI}

- stopniowe ograniczanie zdolności

JST do zaciagania długów

- próby zmniejszenia PDP poprzez

redukcję zadłużenia samorządów

• „nominalny” wzrost zadłużenia JST

- realny wzrost zadłużenia JST

• zmniejszenie „przestrzeni fiskalnej”

samorządu terytorialnego

- presja na sprzedaż majątku

komunalnego

- uzależnienie dochodów JST od często niestabilnych rozwiązań systemowych

- potrzeba angażowania relatywnie większych środków własnych

Źródło: opracowanie własne.

Innym źródłem ryzyka finansowego są procesy debudżetyzacji, czyli przesuwania zadań, ale również środków finansowych i długu samorządowego do spółek z udziałem samorządu (głównie spółek komunalnych) ${ }^{6}$. Te procesy są jednocześnie stymulowane przez nowe reguły fiskalne i ich celem w dużym stopniu jest przeciwdziałanie potencjalnym skutkom utraty elastyczności w kształtowaniu gospodarki finansowej oraz przekroczenia limitu dopuszczalnego zadłużenia ( $z$ wszystkimi tego konsekwencjami). W kontekście regulacji prawnych, wynikających z UoFP oraz rozporządzeń Ministra Finansów, warto równocześnie wspomnieć o nowej definicji długu samorządowego, która w znaczącym stopniu rozszerzyła katalog instrumentów zalicza-

${ }^{6}$ Zadłużenie spółek komunalnych, a także innych spółek prawa handlowego, w których udziały maja JST, pozostaje poza ewidencją długu publicznego, gdyż spółki te w świetle prawa nie podlegaja regulacjom UoFP, lecz kodeksowi spółek handlowych [Poniatowicz, 2011, s. 203]. 
nych do publicznego długu JST7 . W efekcie nastapił „nominalny” wzrost zadłużenia JST, a możliwości zaciagania zobowiązań niezaliczanych do formalnego zadłużenia uległy ograniczeniu. Nowe regulacje w UoFP znacznie redukują swobodę zadłużania jednostek samorządowych, jednakże rygorystycznym pod tym względem działaniom ustawodawcy i rządu towarzyszą różne, praktyczne działania zmierzające do ukrywania długu samorządowego [Poniatowicz, 2011, s. 203-216] lub przenoszenia jego ciężaru na przyszłe pokolenia.

\section{Podsumowanie}

Ryzyko finansowe, łączące się z działalnością JST, jest naturalną konsekwencją realizacji zadań publicznych przez samorząd terytorialny oraz poszukiwania różnych źródeł finansowania w tym zakresie. Ryzyko to ściśle wiąże się z: procedurą zaciagania samorządowego długu publicznego, wyborem instrumentów finansowania i skutkami ich zastosowania, jak również zobowiązaniami dłużnymi niezaliczanymi do samorządowego długu publicznego. W procesie zaciagania zobowiązań o charakterze dłużnym, w okresie wykorzystania środków pozyskanych ze źródeł obcych i spłacie długu występuje ryzyko, którego skutki mogą dotykać wielu obszarów gospodarki finansowej JST oraz wpływać na skuteczność i efektywność realizacji zadań publicznych przez JST.

Jak wykazano w opracowaniu, jednym z kluczowych obszarów kreacji ryzyka finansowego jest nadmierne zadłużenie JST. Jednak należy podkreślić, iż ryzyko to jest jednocześnie pochodną: samodzielności finansowej JST, jakości zarządzania płynnościa, jakości polityki inwestycyjnej i innych obszarów gospodarki finansowej samorządu terytorialnego.

Obecnie zarówno regulacje prawne obejmujące finanse publiczne, jak i praktyka samorządowa wskazują na konieczność uwzględniania w procesie decyzyjnym (dotyczącym źródeł, poziomu i struktury finansowania zadań JST) podstaw, instrumentów i zasad zarządzania ryzykiem finansowym. Zważywszy na współzależność ryzyka finansowego i zadłużenia, zasadniczym obszarem w tym zakresie jest prowadzenie odpowiedniej polityki zarządzania ryzykiem finansowym i zadłużeniem, a w dłuższym okresie strategii zarządzania samorządowym długiem publicznym. Wobec zmienności otoczenia makroekonomicznego i regulacyjnego, cykliczności polityki fiskalnej państwa, a także zmienności sytuacji ekonomiczno-finansowej samej JST, zarządzanie długiem wymaga działań planowych, długofalowych i podporządkowanych realizacji ogólnej strategii jednostki samorządu terytorialnego. Takie podejście pozwala na ograniczanie poziomu ryzyka finansowego.

Głównym wyznacznikiem zarządzania ryzykiem finansowym w samorządzie terytorialnym powinno być zapewnienie bezpieczeństwa finansowego danej jednostki, długookresowej stabilności finansowej oraz redukcja kosztów pozyskiwania funduszy na finansowanie zadań publicznych.

${ }^{7}$ Rozporzadzeniem Ministra Finansów z dnia 23 grudnia 2010 roku w sprawie szczegótowego sposobu klasyfikacii tytutón dtuzinych zaliczanych do państwowego dtugu publicznego, w tym do dtugu Skarbu Państwa (Dz. U. Nr 252, poz. 1692). 


\section{Literatura}

Alesina A., Roubini N.,. Cohen G. 1997 Political Cycles and the Macroeconomy, MIT Press, Cambridge - Massachusetts, London.

Bober J., Hauser J., Izdebski H., Lachiewicz W., Mazur S., Nielicki A., Nowatorski B., Puzyna W., Surówka K., Zachariasz I., Zawicki M. 2013 Narastajace dysfunkcje, zasadnicze dylematy, koniecżne driałania. Raport o stanie samorzadności terytorialnej w Polsce, MSAP, Kraków.

Borys G. 1996 Zarzadzanie rysykiem kredytonym w banku, Wydawnictwo Naukowe PWN, Warszawa.

Czudec A., Kata R. 2013 Zadtušenie a sytuacja ekonomiczzna i rysylko finansowe jednostek samorzadu terytorialnego, „Finanse Komunalne”, nr 5/2013.

Domański C. 2011 Nieklasyczne metody oceny efektywności i rysylka. Otwarte fundusze emerytalne, PWE, Warszawa.

Filipiak B. 2011 Finanse samorzadowe. Nowe nyzwania bieżqce i perspektywiczne, Wydawnictwo Difin, Warszawa.

Gajdka J. 2002 Teorie struktury kapitatu i ich aplikacja w warunkach polskich, Wydawnictwo Uniwersytetu Łódzkiego, Łódź.

Guziejewska B. 2007 Subwencje i dotacje dla samorzqdu terytorialnego w polityce finansowej państwa, „Gospodarka Narodowa”, nr 4/2007.

Jajuga K. 2007 Elementy nauki o finansach, PWE, Warszawa.

Kata R. 2012 Rysylko finansowe w driałalności jednostek samorzadu terytorialnego - metody oceny, „Ekonomika i Organizacja Gospodarki Żywnościowej”, nr 96.

Kluza K. 2013 Przestrzenne zróżnicowanie zadtuìenia jednostek samorzadu terytorialnego w latach 2007-2012, „Człowiek i Środowisko”, 37 (1-2).

KnightF. H. 1921 Risk Uncertainty and Profit, University of Boston Press, Boston.

Kosek-Wojnar M. 2005 Problem niewyplacalności jednostek samorzadu terytorialnego - rysylko bankructwa?, [w:] Samorzad terytorialny w zintegrowanej Europie, Uniwersytet Szczeciński, Szczecin.

KR RIO 2014 Sprawozdanie z. driałalności Regionalmych Iz̧b Obrachunkonych i mykonania budżetu przez jednostki samorzadu terytorialnego w 2013 roku, Krajowa Rada RIO, Warszawa.

Marchewka-Bartkowiak K. 2010 Reguty fiskalne, „Analizy BAS”, nr 7(32).

Owsiak S. 2011 Sytuacja finansowa jednostek samorzadu terytorialnego w Polsce w warunkach spowolnienia gospodarczego, „Ekonomiczne Problemy Usług”, nr 72.

Owsiak S. 2013 Finanse publiczne. Teoria i praktyka, Wydawnictwo Naukowe PWN, Warszawa.

Pfeffer J. 1956 Insurance and Economic Theory, Irvin Inc. Homewood, Illinois.

Poniatowicz M. 2011 Ukerywanie dtugu jednostek samorzadu terytorialnego w Polsce - problem realny çy marginalny, „Ekonomiczne Problemy Usług”, nr 72.

Poniatowicz M. 2012 Reguly fiskalne jako instrument stabilizacji finansowej w sektorze samorzadonym, [w:] Stabilność systemu finansowego - instytucje, instrumenty, uwarunkowania, Wydawnictwo CeDeWu, Warszawa. 
Poniatowicz M., Salachna J., Perło D. 2010 Efektywne zarzqdzanie dtugiem w jednostce samorzqdu terytorialnego, Wolters Kluwer, Warszawa.

Rowe D.W. 1977 An Anatomy of Risk, R.E. Krieger Publishing Company, New York.

Surówka K. 2014 Problem oceny poziomu zadtużenia jednostek samorzqdu terytorialnego a realizacja zadań, „Finanse Komunalne”, nr 9. 